\title{
IgE induces proliferation in human airway smooth muscle cells: role of MAPK and STAT3 pathways
}

\author{
Naresh Singh Redhu' ${ }^{1,2}$, Lianyu Shan ${ }^{1}$, Duaa Al-Subait ${ }^{1}$, Heather L Ashdown ${ }^{1}$, Hesam Movassagh ${ }^{1}$, \\ Bouchaib Lamkhioued ${ }^{3}$ and Abdelilah S Gounni ${ }^{*}$
}

\begin{abstract}
Airway remodeling is not specifically targeted by current asthma medications, partly owing to the lack of understanding of remodeling mechanisms, altogether posing great challenges in asthma treatment. Increased airway smooth muscle (ASM) mass due to hyperplasia/hypertrophy contributes significantly to overall airway remodeling and correlates with decline in lung function. Recent evidence suggests that lgE sensitization can enhance the survival and mediator release in inflammatory cells. Human ASM (HASM) cells express both low affinity (FcERII/CD23) and high affinity IgE Fc receptors (FcERI), and IgE can modulate the contractile and synthetic function of HASM cells. IgE was recently shown to induce HASM cell proliferation but the detailed mechanisms remain unknown. We report here that IgE sensitization induces HASM cell proliferation, as measured by ${ }^{3} \mathrm{H}$-thymidine, EdU incorporation, and manual cell counting. As an upstream signature component of FcERl signaling, inhibition of spleen tyrosine kinase (Syk) abrogated the IgE-induced HASM proliferation. Further analysis of IgE-induced signaling depicted an IgE-mediated activation of Erk 1/2, p38, JNK MAPK, and Akt kinases. Lastly, lentiviral-shRNA-mediated STAT3 silencing completely abolished the IgE-mediated HASM cell proliferation. Collectively, our data provide mechanisms of a novel function of IgE which may contribute, at least in part, to airway remodeling observed in allergic asthma by directly inducing HASM cell proliferation.
\end{abstract}

Keywords: Human, Airway remodeling, EdU incorporation, Airway smooth muscle, Syk, MAPK, STAT3

\section{Introduction}

Nearly $80 \%$ of children and more than $50 \%$ of adult asthma is thought to be allergic/immunoglobulin $\mathrm{E}$ (IgE)dependent [1]. Classical dogma defines the allergic reaction in two steps; first when antigen-specific IgE binds to its high affinity Fc receptor (FceRI) on mast cells and basophils (sensitization step). Next, antigen/allergen binding to specific IgE 'cross-links' the FceRI which culminates in various cell activation events such as degranulation, de novo synthesis and secretion of inflammatory mediators, and promotion of cell survival and migration [2]. However, recent studies have established a new paradigm in which IgE sensitization alone can induce a spectrum of effects such as the release of proinflammatory cytokines and chemokines, inhibition of apoptosis or induction of pro-survival effects through activation of various signaling

\footnotetext{
* Correspondence: abdel.gounni@med.umanitoba.ca

'Department of Immunology, Faculty of Medicine, University of Manitoba, 419 Apotex Centre- 750 McDermot Ave, Winnipeg, MB R3E OT5, Canada Full list of author information is available at the end of the article
}

pathways. So far, monomeric IgE has been shown to enhance the survival of mast cells, monocytes, and asthmatic neutrophils $[2,3]$.

Airway smooth muscle (ASM) cells are structural entities of airways which are believed to confer an abnormally exaggerated bronchoconstriction in asthma, the phenomenon commonly known as airway hyperresponsiveness (AHR). Clinically, majority of asthma patients show a significant increase in ASM bundles, likely due to increase in cell number, collectively contributing to airway remodeling [4]. Tissue remodeling due to increased ASM mass in allergic asthma is also known to correlate with AHR in some patients [5]. Although precise mechanisms remain yet to be established, an increase in cell number (hyperplasia) is suggested to be one of the primary factors underlying this increase in ASM mass $[4,6]$. Molecular studies suggest that mitogen activated protein kinases (MAPK) family and signal transducer and activator of transcription (STAT) 3, besides other pathways, play pivotal role in regulating ASM cell proliferation under various contexts $[7,8]$. 
Serum IgE levels have been shown earlier to modulate smooth muscle function. Bronchial hyperresponsiveness was shown to be associated with serum IgE levels [9]. IgE was also shown to cause smooth muscle contractile function through binding to the smooth muscle membrane and subsequent hyperpolarization [10]. We and others have demonstrated previously that human ASM (HASM) cells express a functional tetrameric high affinity FceRI $(\alpha \beta \gamma 2)$. IgE/anti-IgE stimulation of HASM induced the release of Th2 and proinflammatory mediators IL-4, -5, -13, TNF, IL-6, CCL11/eotaxin-1, and thymic stromal lymphopoietin (TSLP), and enhanced intracellular calcium $\left(\left[\mathrm{Ca}^{2+}\right] \mathrm{i}\right)$ mobilization $[11,12]$. Cumulative evidence has established a critical role of IgE/FceR interaction in modulation of HASM function and phenotype [12-15]. Although IgEinduced ASM proliferation was reported recently [16], the molecular mechanisms remain unknown. We show here that IgE induces proliferation of ASM cells via MAPK, Akt, and STAT3 signaling pathways; suggesting that IgE may indeed contribute, at least partly, to the development of airway remodeling in allergic asthma.

\section{Materials and methods Reagents}

Recombinant human IgE was obtained from Diatec (BioPorto Diagnostics A/S, Denmark). Fetal bovine serum (FBS), sodium pyruvate, trypsin were purchased from HyClone (Logan, UT, USA). 100× L-glutamine, DMEM, Ham's F-12, trypsin-EDTA, and antibiotics (penicillin, streptomycin) were purchased from Invitrogen Canada Inc. (Burlington, ON, Canada). Platelet-derived growth factorBB (PDGF-BB) was from R\&D Systems, Minneapolis, MN, USA). Rabbit anti-human p38 MAPK mAb, affinitypurified mouse anti-phospho-ERK1/2 (T202/Y204), rabbit anti-human ERK1/2 mAb, affinity-purified rabbit antiphospho-p38 MAPK (T180/Y182), rabbit anti-total and phospho-specific SAPK/JNK (T183/Y185) Abs, rabbit mAb phospho-Akt (Ser 473) and total-Akt antibody were purchased from Cell Signaling Technology, Inc (Danvers, MA). Mouse mAb anti-phospho-tyrosine STAT3 (Y705) was from BD Biosciences (Mississauga, ON). Affinity purified rabbit anti-total STAT3 antibody and rabbit polyclonal anti-Syk (C-20) antibody were from Santa Cruz Biotechnology, Inc. (Santa Cruz, CA). The p38 MAPK inhibitor, SB203580; JNK inhibitor, SP-600125; p42/p44 ERK inhibitor, U-0126; and cell-permeable Akt inhibitor VII, TAT-Akt-in were purchased from CALBIOCHEM ${ }^{\circledR}$ (EMD Millipore), San Diego, CA, USA. Unless stated otherwise, all other reagents were obtained from Sigma-Aldrich Canada Ltd. (Oakville, ON, Canada).

\section{Culture and stimulation of HASM cells}

HASM cells were prepared and maintained as we have reported earlier $[11,17,18]$. Written informed consent was obtained from the tissue donors, and this study was approved by the research ethics committee of the University of Manitoba, Winnipeg, Canada. In all experiments, sub-confluent HASM cells were growth arrested and synchronized by serum deprivation for $48 \mathrm{~h}$ in Ham's F-12 medium containing $1 \times$ ITS $(5 \mu \mathrm{g} / \mathrm{ml}$ human recombinant insulin, $5 \mu \mathrm{g} / \mathrm{ml}$ human transferrin, $5 \mathrm{ng} / \mathrm{ml}$ selenium), and antibiotics (100 U/ml penicillin and $100 \mu \mathrm{g} / \mathrm{ml}$ streptomycin). Cells were then stimulated in fresh FBSfree medium with agonists for indicated time periods.

\section{Manual cell counting and ${ }^{3} \mathrm{H}$-thymidine incorporation to measure HASM cell proliferation}

HASM cell proliferation was measured by manual cell counting. Tritiated $\left({ }^{3} \mathrm{H}\right)$-thymidine incorporation assay was performed to measure DNA synthesis as a surrogate marker of cell proliferation by following the method of Goncharova and colleagues [19] with minor modifications. Briefly, ASM cells were seeded in 24-well tissue culture plates $\left(3 \times 10^{4}\right.$ cells/well) to grow to about $70 \%$ confluency in a $37^{\circ} \mathrm{C}$ humidified $5 \% \mathrm{CO}_{2}$ incubator. Cells were serum-deprived in Ham's F12 containing $1 \times$ ITS media for $48 \mathrm{~h}$ to growth-arrest and synchronize them. Fresh F12 containing $1 \times$ ITS was added and cells were stimulated with graded doses of IgE and other mitogens for $16 \mathrm{~h}$. 10\% FBS or PDGF-BB $(10 \mathrm{ng} / \mathrm{ml})$ was used (following dose titration) as a positive control. After $16 \mathrm{~h}$, methyl- ${ }^{3} \mathrm{H}$-thymidine (Specific activity $20 \mathrm{Ci}[740 \mathrm{GBq}] /$ mMole, >97\%; Perkin Elmer, Woodbridge, ON, Canada) was added at a final concentration of $2 \mu \mathrm{Ci} / \mathrm{ml}$ and cells were incubated at $37^{\circ} \mathrm{C}$ for $24 \mathrm{~h}$. Subsequently, ASM cells were rinsed in PBS three times before adding $0.1 \mathrm{ml}$ $0.05 \%$ trypsin-EDTA for 15 minutes at $37^{\circ} \mathrm{C}$ for lysis, followed by addition of $0.1 \mathrm{ml}$ ice-cold $20 \%$ trichloroacetic acid (TCA) for 20 minutes at $4^{\circ} \mathrm{C}$ to precipitate the DNA. Precipitated DNA was then carefully transferred to 96-well plates to facilitate its absorption on 96-well format glass fibre filter mats (Wallac, Turku, Finland) using Tomtec Harvestor 96 (Tomtec Inc., Hamden, CT, USA). Filter mats were air-dried and counted in liquid scintillation counter. In some experiments, MAPK inhibitors were used for one hour prior to IgE stimulation. Experiments were performed in triplicate and the data was presented as mean \pm SEM of counts per minute (cpm).

\section{EdU-incorporation assay for HASM cell proliferation}

HASM cell proliferation was additionally measured by using Click-it EdU Proliferation kit (Invitrogen) by following the manufacturer's instructions. Briefly, subconfluent $48 \mathrm{~h}$ serum-starved ASM cells were stimulated with graded doses of IgE $(5-25 \mu \mathrm{g} / \mathrm{ml})$ and PDGF $(10 \mathrm{ng} / \mathrm{ml})$ for $16 \mathrm{~h}$ following which cells were allowed to incorporate EdU (5-ethynyl-2'-deoxyuridine; $5 \mu \mathrm{M}$ ) for $24 \mathrm{~h}$ and then trypsinized and fixed. Fixed cells were 
immediately processed for staining with Click-it EdU detection reagent conjugated with Alexa Fluor 488, and cell nuclei were stained with DAPI. EdU-positive cells were visualized by using flow cytometry and are presented as \% proliferating population on right side of the histogram.

\section{Western blotting to assess MAPK and STAT3 phosphorylation}

IgE-induced ASM signaling pathways were studied by performing Western blotting for phosphorylated MAPK and STAT3, as described earlier [20]. Intensity of phosphorylation was assessed by performing densitometry analysis using AlphaEaseFC (FluorChem 8800) Software.
The data was presented as fold increase in the ratio of phospho and total compared to time zero.

\section{Lentivirus-mediated STAT3-shRNA transduction in HASM} cells

Lentiviral transduction of Syk-short hairpin (sh) RNA (clone ID: V2LHS_153702) and STAT3-short hairpin (sh) RNA (clone ID: V2LHS_262105) in HASM cells was performed as described earlier [21]. Mock and lentiviralSyk- or lentiviral-STAT3-shRNA-transduced HASM cells were cultured in presence of $\operatorname{IgE}(10 \mu \mathrm{g} / \mathrm{ml})$, PDGF-BB (10 ng/ml), FBS (10\%), or medium alone; and cell proliferation was assessed by ${ }^{3} \mathrm{H}$-thymidine incorporation assay.
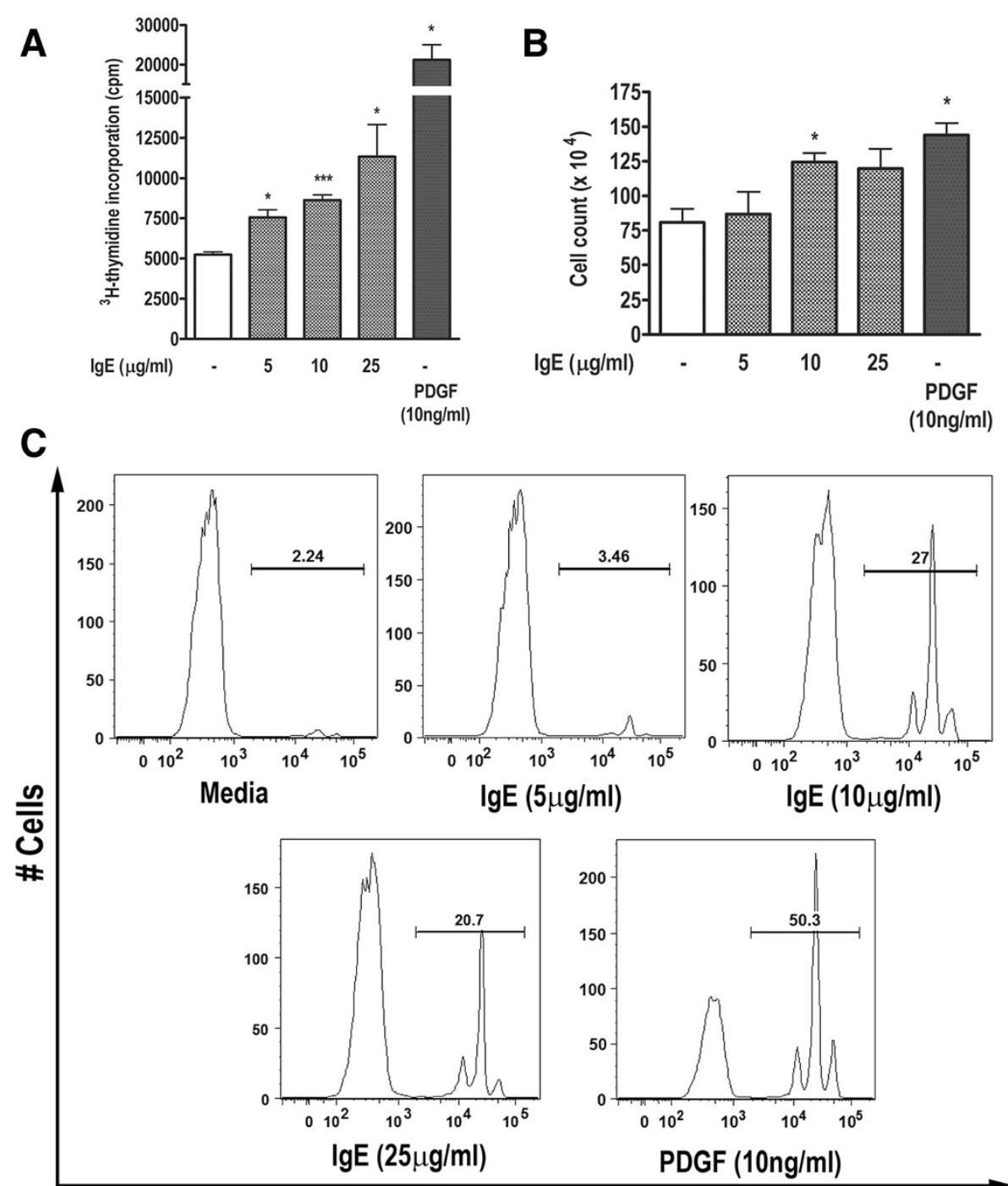

\section{EdU incorporation (proliferating cells)}

Figure 1 lgE induces DNA synthesis and cell proliferation in HASM cells. (A) Serum-starved HASM cells were stimulated with lgE (5-25 $\mu \mathrm{g} /$ $\mathrm{ml})$, PDGF-BB $(10 \mathrm{ng} / \mathrm{ml})$, or left unstimulated. ${ }^{3} \mathrm{H}$-thymidine incorporation was measured by liquid scintillation counting and presented as $\mathrm{cpm}$. (B) IgE or PDGF-BB-stimulated cells were trypsinized after $48 \mathrm{~h}$ and counted by hemocytometer. (C) HASM cells stimulated similar to (A) were subjected to EdU-incorporation assay. EdU positive cell populations from a representative experiment are shown. $n=3 ;{ }^{*} p<0.05,{ }^{* * *} p<0.001$ compared to unstimulated control. 


\section{Statistical analysis}

Statistical analysis was performed by using GraphPad Prism Software Version 3.02 for Windows (GraphPad Software, San Diego, CA, USA). Data between groups was compared by using student's unpaired $t$ test. P values $<0.05$ were considered statistically significant.

\section{Results}

IgE induces DNA synthesis and proliferation in HASM cells To test the mitogenic potential of IgE on human ASM cells, we performed ${ }^{3} \mathrm{H}$-thymidine incorporation assay. While IgE did not affect cell survival (data not shown); as shown in Figure 1A, IgE induced de novo DNA synthesis in HASM cells $(n=5, p<0.05)$. As expected, PDGF induced prominent increase in DNA synthesis and served as positive control $[8,18]$. We further validated the IgE-induced ${ }^{3} \mathrm{H}$ thymidine incorporation data by using hemocytometerbased cell counting. IgE-induced thymidine incorporation appeared to have translated into increase in cell number compared to control (Figure $1 \mathrm{~B}, \mathrm{n}=4, \mathrm{p}<0.05$ ), suggesting that IgE is able to induce DNA synthesis and subsequent proliferation in HASM cells (Figure 1A, B).

In addition, we confirmed the proliferative effect of IgE on HASM cells by using EdU incorporation. As shown in Figure $1 \mathrm{C}$, IgE clearly induced HASM cell proliferation, in almost similar manner to ${ }^{3} \mathrm{H}$-thymidine incorporation and manual cell counting (Figure 1). Therefore, our data suggest that IgE can induce HASM cell proliferation.

\section{Lentivirus-mediated Syk inhibition abrogates IgE-induced HASM proliferation}

FceRI activation leads to a spectrum of signaling events in inflammatory cells, starting with phosphorylation of Lyn kinase followed by recruitment and phosphorylation of Syk. Activation of Syk then serves as an indispensable mechanism of downstream propagation of signals leading to the activation of various kinases, transcription factors, mediator release, and survival [2,22,23]. This suggests that inhibition/silencing of Syk might be a useful strategy to validate the role of Syk and FceRI pathway in IgE-induced HASM cell proliferation. To test this, we utilized the lentiviral-mediated Syk inhibition strategy, which we have reported earlier in IgE-induced mediator release in HASM cells $[15,17]$. HASM cells were stably transduced with pseudotyped lentiviral vector expressing specific Syk-shRNA. Mock and scramble sequence were used as negative controls. As reported earlier [15,17], more than $95 \%$ of HASM cells were transduced by turboGFP signal positivity by FACS analysis (data not shown). Lentiviral-Syk-shRNA but not control scramble-shRNA transduction resulted in a highly significant and reproducible decrease in Syk expression, as shown by Western blotting (Figure 2A). We then used these lentiviraltransduced cells and stimulated them with IgE and PDGF.
As shown in Figure 2B, scramble-shRNA-transduced HASM cells demonstrated a significant increase in thymidine incorporation $(\mathrm{p}<0.05, \mathrm{n}=3)$ similar to the wildtype cells (Figure 1A). However, Syk-shRNA-transduced cells lost the effect of IgE ( $\mathrm{p}>0.05$, non-significant). PDGF consistently showed highly significant $(\mathrm{p}<0.001)$ thymidine incorporation in both scramble and Syk-inhibited HASM cells (Figure 2B). These results suggest that IgEinduced proliferation requires the function of Syk, a key signaling pathway in FceRI activation.

\section{IgE activates multiple signaling pathways in HASM cells}

To understand the downstream molecular signaling pathways involved in IgE-induced HASM cell proliferation, we assessed the phosphorylation of MAPK and Akt by performing Western blot analysis on HASM cell lysates stimulated with IgE for 0-120 min. Western blotting revealed a significant JNK phosphorylation at 20-30 min, Erk1/2 at $60 \mathrm{~min}, \mathrm{p} 38$ at $120 \mathrm{~min}$, and Akt at $60 \mathrm{~min}$ $(\mathrm{n}=3$, Figure $3 \mathrm{~A}, \mathrm{~B})$. In summary, IgE phosphorylates MAPK and Akt kinases in HASM cells which may play a role in IgE-induced cell proliferation.

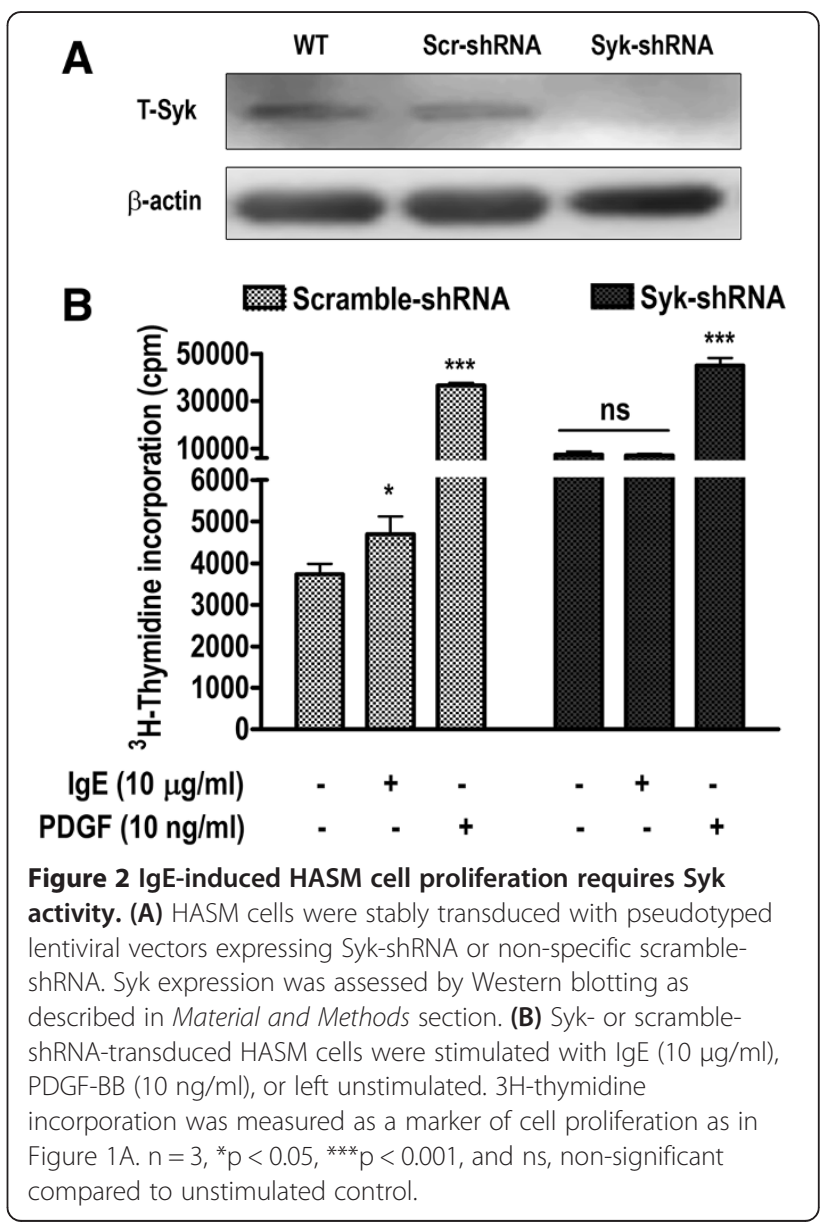




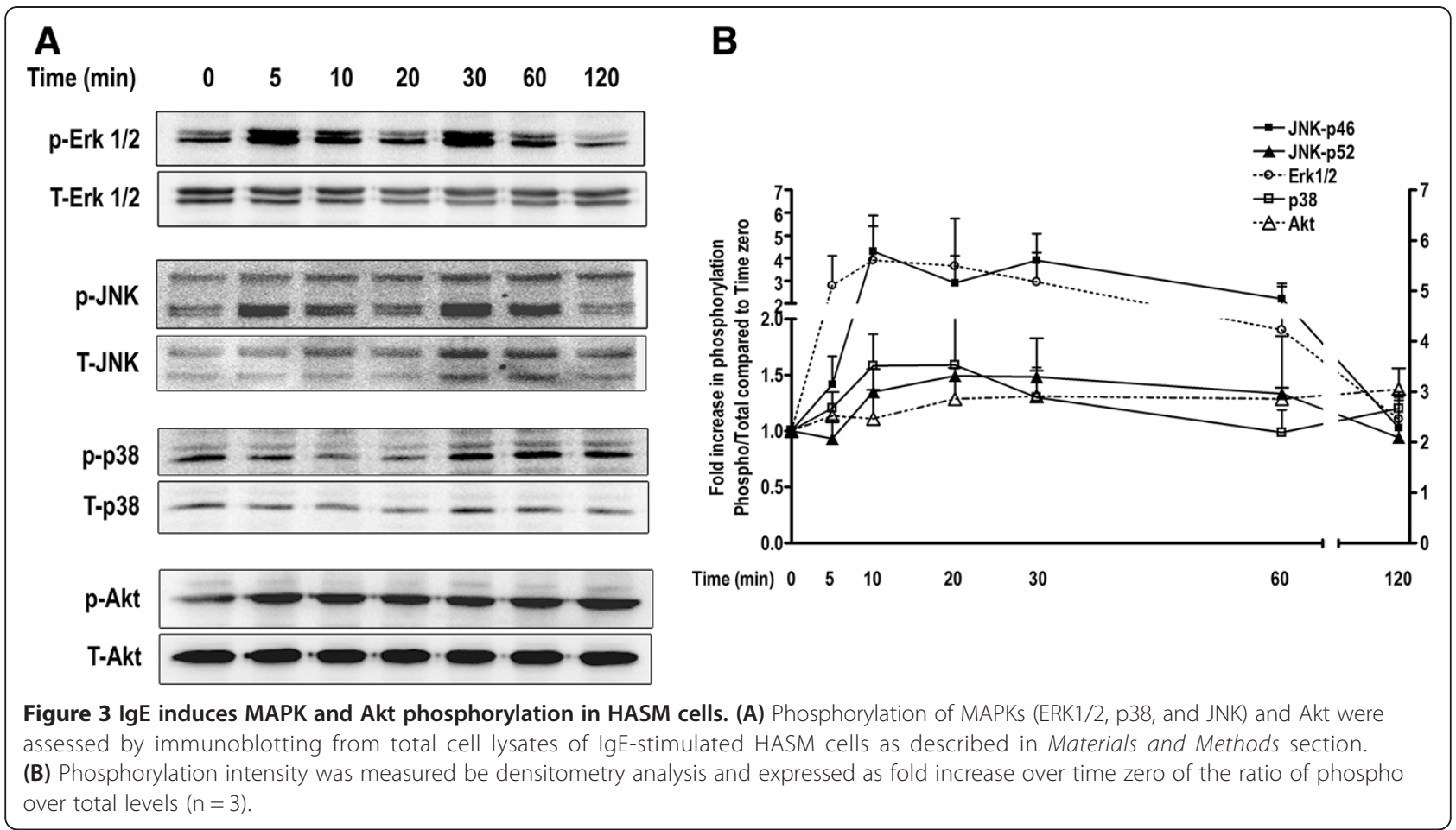

\section{MAPK inhibitors abrogate the IgE-induced HASM cell proliferation}

We then confirmed the involvement of different MAPKs in IgE-induced HASM cell proliferation by using specific MAPK inhibitors. The dose of various inhibitors was first optimized to find the dose that inhibits IgEinduced cell proliferation without inducing a noticeable cytotoxicity (data not shown). Figure 4 shows that IgEinduced HASM cell proliferation was inhibited significantly $(\mathrm{p}<0.05, \mathrm{n}=3$ ) upon pre-incubation for one hour with inhibitors of Erk1/2 (1 $\mu \mathrm{M}$, U0126), JNK (10 nM, SP600125), p38 (10 $\mu \mathrm{M}, \mathrm{SB} 203580)$, and Akt $(10 \mu \mathrm{M}$, TAT- $A k t-i n)$. DMSO vehicle control did not show any effect on HASM cell proliferation (data not shown). In conclusion, IgE-induced HASM cell proliferation involves the activation of Erk1/2, p38, JNK MAPK, and Akt kinases.

\section{STAT3 is critical in IgE-induced HASM cell proliferation}

STAT3 activation is indispensable in HASM cell proliferation in response to PDGF [8]. Interestingly, monomeric IgE induces STAT3 phosphorylation in murine bone marrow-derived mast cells and rat basophilic leukemia cells, and induce the transcription of genes important in cell survival [24]. With these reports in consideration, we first sought to determine whether IgE is able to phosphorylate STAT3 in HASM cells. A representative blot in Figure 5A and summary of 4 experiments in Figure 5B show that IgE indeed induced STAT3 phosphorylation in HASM cells. To confirm its role in HASM cell proliferation, we employed lentiviral vector-mediated STAT3 silencing approach [20]. HASM cells were stably transduced with pseudotyped lentiviral vector encoding specific STAT3-shRNA. Mock and scramble sequence served as controls. More than 95\% of HASM cells were transduced as observed by turbo-GFP signal by FACS analysis (data not shown). Lentiviral-STAT3-shRNA transduction resulted in a noticeable decrease in STAT3 expression compared to WT or scramble-shRNA transduction controls (Figure 5C) [21]. Both scrambleshRNA- and STAT3-shRNA-transduced HASM cells were stimulated with IgE and PDGF to analyze thymidine incorporation. Since PDGF-induced mitogenic signaling requires STAT3 expression [8], 10\% FBS was used as an additional positive control in this experiment. As expected, scramble-shRNA-transduced HASM cells showed a normal and statistically significant response to IgE ( $\mathrm{p}<0.05)$, PDGF, and 10\% FBS ( $<<0.001)$ compared with unstimulated control (Figure 5D). However, the effect of IgE was completely abrogated in STAT3-shRNA transduced cells, and so was the effect of PDGF, also confirming the previous reports [8]. On the other hand, although 10\% FBS showed increased thymidine incorporation in STAT3-shRNA-transduced cells, the effect was much less pronounced when compared with scramble-shRNA-transduced HASM cells (Figure 5D). This is consistent with the observation by other groups [8], and suggests that the serum components may also require STAT3 activation to induce 


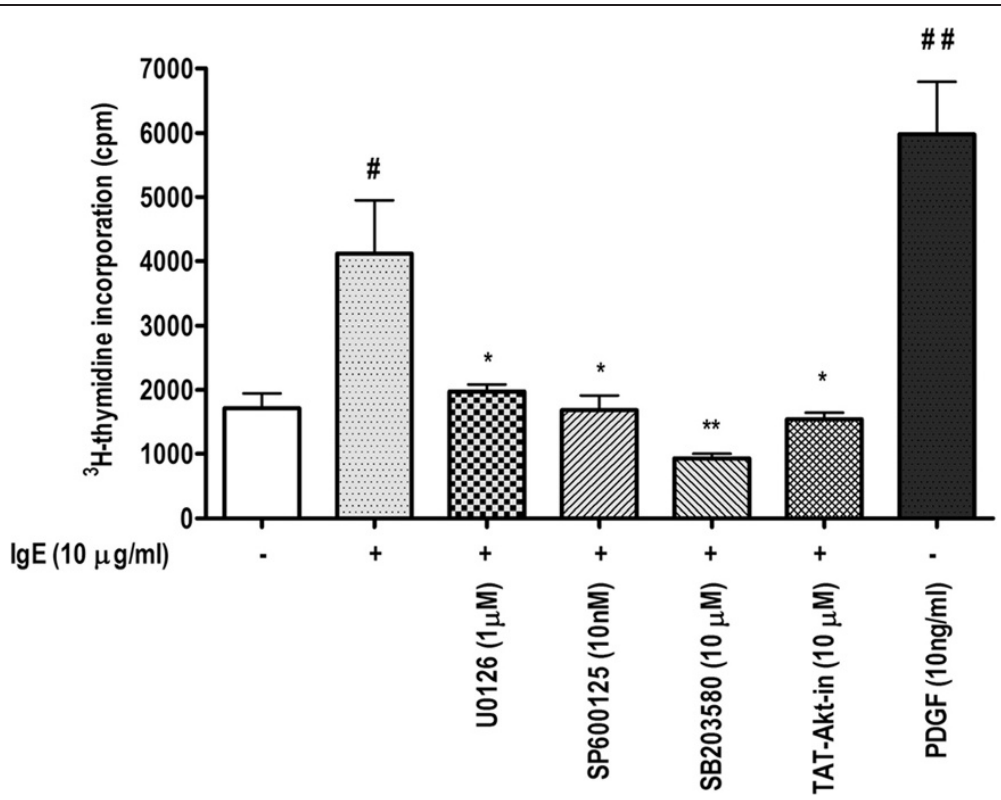

Figure 4 MAPK and Akt inhibitors abrogate the IgE-induced HASM cell proliferation. ${ }^{3} \mathrm{H}$-thymidine incorporation assay was performed in serum-starved HASM cells stimulated with IgE for $24 \mathrm{~h}$ following pretreatment for $1 \mathrm{~h}$ with inhibitors of ERK $1 / 2(1 \mu \mathrm{M}, \mathrm{U} 0126)$, JNK (10 nM,

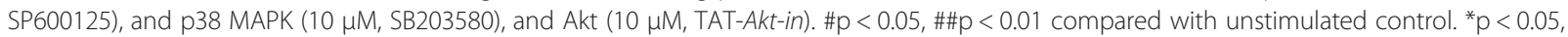
${ }^{* *} \mathrm{p}<0.01$, ns, non-significant compared with IgE-stimulated cells.

mitogenic signaling in HASM cells. In summary, our data suggest that IgE-induced STAT3 activation plays a critical role in HASM cell proliferation.

\section{Discussion}

We report in this study that IgE sensitization induces DNA synthesis and proliferation in HASM cells through the activation of Syk, and signaling Erk 1/2, p38, JNK MAPK, and Akt kinases. Lentivirus-shRNA-mediated experiments showed that STAT3 activation is indispensable for IgE-induced HASM cell proliferation. Collectively, we show for the first time that IgE sensitization can directly induce human ASM cell proliferation which may contribute, at least partly, to the airway remodeling in allergic asthma.

Serum IgE levels were shown to affect ASM cell function and tend to correlate with AHR [9]. Cumulative data in last decade has defined a direct role of IgE in ASM cell activation. We and others have shown that FceRI activation by IgE/anti-IgE incubation leads to enhanced release of proasthmatic cytokines (IL-4, -5, -13, TNF, IL-6, and TSLP), eosinophil-attracting CCL11/eotaxin-1 chemokine; and a rapid and transient increase in $\left(\left[\mathrm{Ca}^{2+}\right] \mathrm{i}\right)$ mobilization, altogether suggesting a critical role of this pathway in airway inflammation and hyperresponsiveness $[11,12,14,15]$. Importantly, blocking of FceRI led to abrogation of IgEinduced HASM cell synthetic functions [11]. Moreover, TNF and IL-4 can augment FceRI expression and amplify IgE-induced release of chemokines including CCL11/ eotaxin-1, CCL5/RANTES, CXCL8/IL-8, and CXCL10/IP10 [17]. Although Xia et al. were unable to demonstrate the expression of FceRI in ASM cells [25], possible explanations for this discrepancy were discussed recently [26]. Furthermore, other groups have shown that $\operatorname{IgE} /$ anti-IgE treatment of HASM cells induce modest levels of matrix metalloprotease 1 (MMP-1) production which may contribute to airway inflammatory and remodeling responses [27]. Finally, a clinically-proven anti-IgE monoclonal antibody Omalizumab abrogated the IgE-induced mediators of asthma relevance such as IL-4, IL-6, IL-8, and TNF [12]. The current study extends the function of IgE on HASM cells by suggesting a direct mitogenic effect which may have critical consequences on airway tissue remodeling. Interestingly, IgE induced significantly higher cell proliferation in ASM cells obtained from asthma compared to that from normal individuals [16]. In vivo, anti-IgE treatment decreased the thickness of ASM layer compared with the ovalbumin (OVA)-challenged mice [28], suggesting that IgE could be one of the factors inducing ASM remodeling in vivo. Although the low affinity (FceRII/CD23) receptor has also been described in ASM cells with enhanced signal in ASM tissue from asthma [29], and Roth et al. have suggested the involvement of both FceRII/CD23 and FceRI in IgE-induced ASM remodeling [16]; presently observed proliferative effect of IgE appear to primarily involve Fc\&RI since the lentiviral shRNA-mediated inhibition of spleen tyrosine kinase (Syk), a signature kinase in FceRI signaling [22], abolished the IgE-induced HASM proliferation. 


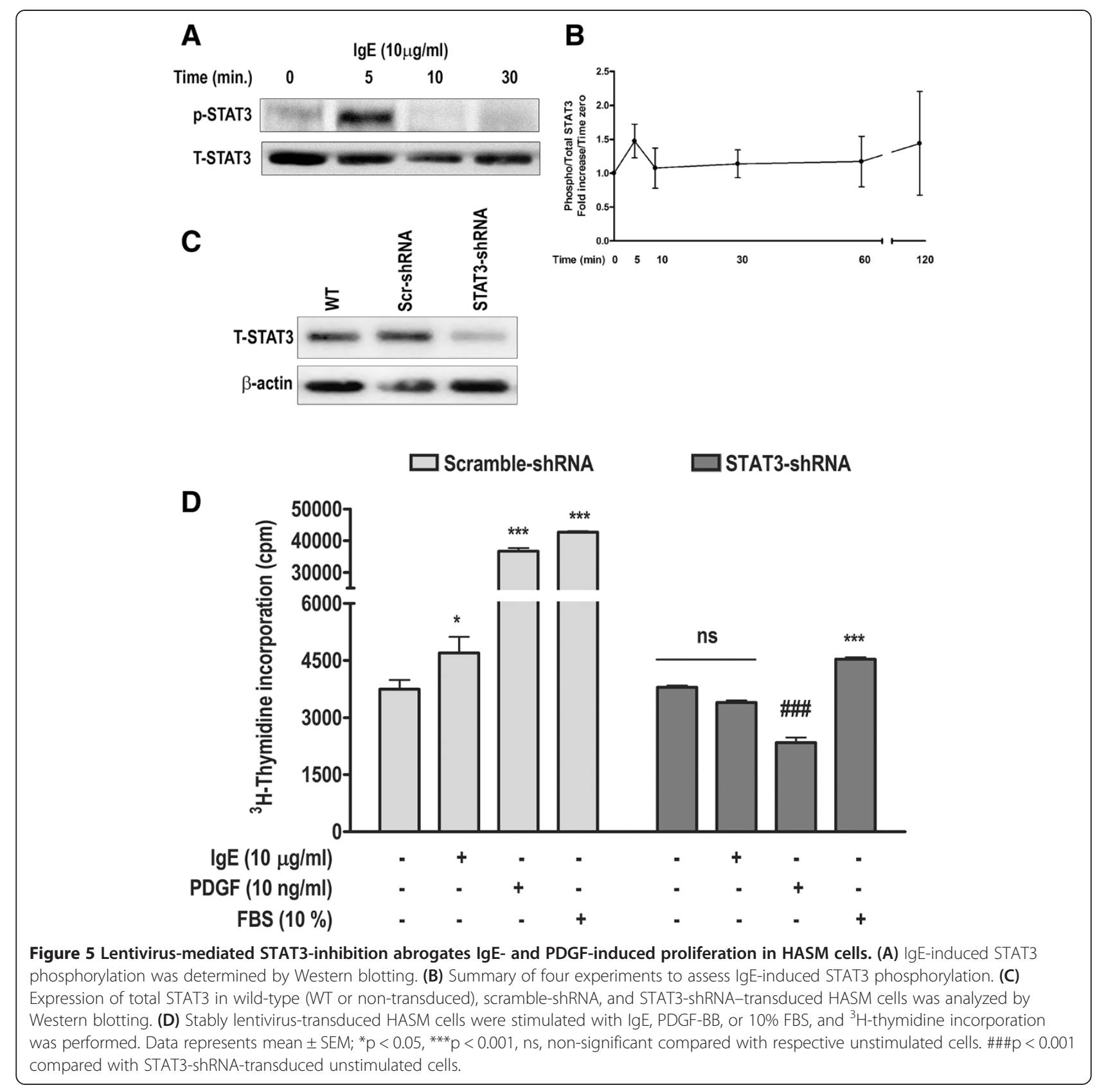

However, the role of FceRII/CD23 in this process cannot be denied. Of note, Syk inhibition in our study led to increase in basal ASM cell proliferation. Previous studies have shown that Syk regulates proliferation and migration in non hematopoietic cells. In Syk knockout mice, aberrant development of the blood and lymphatic vessels is due to abnormal endothelial cell proliferation and migration [30,31]. Furthermore, Syk also regulates breast epithelial cell proliferation, migration, and differentiation. In fact, the absence of Syk correlated with increased aggressiveness and metastases of the tumors. In humans, ductal cell carcinomas [32] and in vitro studies have shown that reconstitution of Syk expression abrogated the abnormal cell proliferation observed in a cancerous breast epithelial cell line [33]. Therefore, the relatively higher basal cell proliferation in our Syk-silenced HASM cells may be attributed to the fundamental nature of Syk in regulating the cell proliferation.

STAT3 has been shown earlier to regulate allergic response in asthma. Particularly, epithelial STAT3 was identified as a critical regulator of allergen-induced inflammation and AHR in a murine model of asthma [34], IL-17A-induced STAT3 activation led to CCL11/ eotaxin-1 production in HASM [21], and PDGF-induced 
STAT3 mediated the proliferation in HASM cells [8]. Besides PDGF, IgE was shown to induce STAT3-dependent transcription of pro-survival genes in mast cells [24]. We observed a clear phosphorylation of STAT3 in response to IgE, the functional role of which was confirmed by lentivirus-shRNA-mediated STAT3 inhibition that completely abrogated the IgE-induced HASM cell proliferation. Interestingly, although both PDGF and IgE activated STAT3, we did not observe any synergy between both in modulating HASM cell proliferation (data not shown).

Although IgE-induced signaling pathways are well characterized in inflammatory cells, there is limited information on this area in HASM cells. MAPK family is fundamental in regulating multiple cell functions such as cytokine expression, proliferation, and apoptosis. Although Erk1/2 and p38 MAPK were shown to mediate IgE-induced proinflammatory gene expression in HASM recently [12], Akt was observed to be activated in response to IgE for the first time in HASM. However, the role of Akt (also called protein kinase B) is well defined in HASM cell mitogenic signaling [35]. The p38 MAPK is also known for its pro-remodeling function in allergic asthma [36]. Furthermore, studies show that MAPK (at least ERK1/2) can modulate the STAT3 activation in HASM [21,37]. However, it is unclear and deserves further investigation whether MAPK and STAT3 signaling pathways cross-talk to induce IgE-mediated proliferation. Collectively, IgE induced the activation of multiple signaling pathways (ERK1/2, p38, JNK MAPK and STAT3) which suggests a complex network of signaling pathways in mediating IgE-FceR signaling in HASM cells. Further studies are underway to delineate these cross-regulatory interactions in HASM cell proliferation.

Mechanistically, there is sufficient evidence from past decade to convince that the 'IgE sensitization/monomeric IgE exposure' of FceRI on inflammatory cells itself can activate multiple signaling pathways; induce a plethora of proinflammatory mediators release and cell survival factors, and subsequent repression of apoptosis [38]. Interestingly, IgE-induced survival or cytokine release does not necessarily require receptor aggregation and merely receptor occupancy can induce these effects [39-42]. Nonetheless, the role of FceRI cross-linking in conferring pro-survival effect has been a matter of debate. While two initial reports $[39,40]$ suggested the lack of cross-linking, Xiang et al. [43] argued for FceRI crosslinking-mediated degranulation in mast cell survival. IgE induced monocyte survival in both instances (aggregation or no aggregation), while mast cells and asthmatic neutrophils showed IgE-mediated survival without FceRI cross-linking or aggregation [3,41]. These findings are supported by in vivo observations where IgE can promote immune sensitization to hapten in the skin, without the need of antigens [44]. Not only monoclonal IgE, a recent report suggest that the polyclonal IgE from human atopic dermatitis patients can induce survival effects and cytokine release in human cord blood-derived mast cells, a finding that is clinically more relevant [45]. Of note, HASM cells have been shown to be activated by both 'sensitization alone' $[12,15,17]$ and 'cross-linking' $[11,27]$ models. Whether the currently observed mitogenic effects of IgE on HASM cell require cross-linking/aggregation is not clear. However, the cross-linking of FceRIbound IgE with anti-IgE antibodies from various sources did not further augment the HASM cell thymidine incorporation in our study (data not shown). In conclusion, our data suggest that the mitogenic effect of IgE on HASM cells may occur through simple receptor occupancy without cross-linking.

Omalizumab, the clinically approved anti-IgE antibody blocks the interaction of IgE with FceRI and has shown clinical benefits in controlling allergic inflammation, and offered improvement in asthma symptoms, reduced frequency of asthma exacerbations, and significantly lowered the use of inhaled corticosteroids [46,47]. Finally, the proposal that IgE can induce ASM remodeling is bolstered by two recent clinical studies wherein clinical anti-IgE antibody treatment significantly reduced the airway wall thickness and airway inflammation in severe allergic asthma $[16,48,49]$. Importantly, anti-IgE therapy may not be the best approach for clinical benefit since IgE already bound to mast cells and basophils and residual IgE can still trigger cell activation. Blocking the Fc\&RI may be a theoretically better approach. Recent studies have showed that a novel FceRI-mimetic peptide E (PepE) can block IgE binding to FceRI and can prevent anaphylaxis in WT mice but has no capacity of blocking anaphylaxis in IgE KO mice that was given IgE before treatment [50]. This suggests that PepE can block the binding of free IgE to FceRI but cannot compete with the receptor for already bound IgE in vivo. In conclusion, blocking the IgE-FceR interaction, not only on inflammatory cells but also on the airway structural (HASM) cells should be considered as a novel tool to inhibit allergic sensitization-mediated airway remodeling in asthma.

\section{Competing interests}

The authors declare that they have no competing interests.

\section{Authors' contributions}

NSR and ASG conceived the study, NSR performed the experiments, analyzed the data, and wrote the manuscript; LS, DA, HLA, HM performed the experiments; BL provided critical scientific input; ASG provided the resources, and provided editorial and scientific input on manuscript. All authors read and approved the final manuscript.

\section{Acknowledgements}

Authors wish to thank Dr. Ali Saleh (St. Boniface General Hospital Research Centre, Winnipeg), and Dr. Sam KP Kung lab for assistance with the lentiviral vector work. We would like to thank Dr Andrew J. Halayko (Department of Physiology, University of Manitoba) and Dr Thomas Murphy (Duke University) for providing us with human ASM cells. 
This work is supported by the Canadian Institutes of Health Research (CIHR) ASG is funded by the Manitoba Research Chairs program. NSR is a recipient of the Canadian Thoracic Society-Canada Lung Association (CTS-CLA) National Graduate studentship award.

\section{Author details}

${ }^{1}$ Department of Immunology, Faculty of Medicine, University of Manitoba 419 Apotex Centre- 750 McDermot Ave, Winnipeg, MB R3E 0T5, Canada. ${ }^{2}$ Current address: Department of GI/Nutrition, Boston Children's Hospital, Harvard Medical School, Boston, MA 02115, USA. ${ }^{3}$ UFR de Pharmacie, Universite de Reims, Champenne-Ardene, Reims, France.

Received: 26 June 2013 Accepted: 1 October 2013

Published: 17 October 2013

\section{References}

1. Hamelmann E: The rationale for treating allergic asthma with anti-IgE. Eur Respir Rev 2007, 16:61-66.

2. Kawakami T, Galli SJ: Regulation of mast-cell and basophil function and survival by IgE. Nat Rev Immunol 2002, 2:773-786.

3. Saffar AS, Alphonse MP, Shan L, Hayglass KT, Simons FE, Gounni AS: IgE modulates neutrophil survival in asthma: role of mitochondrial pathway. J Immunol 2007, 178:2535-2541.

4. Mauad T, Bel EH, Sterk PJ: Asthma therapy and airway remodeling. J Allergy Clin Immunol 2007, 120:997-1009. quiz 1010-1001.

5. Tsurikisawa N, Oshikata C, Tsuburai T, Saito H, Sekiya K, Tanimoto H, Takeichi $\mathrm{S}$, Mitomi $\mathrm{H}$, Akiyama K: Bronchial hyperresponsiveness to histamine correlates with airway remodelling in adults with asthma. Respir Med 2010, 104:1271-1277

6. Bara I, Ozier A, Tunon de Lara JM, Marthan R, Berger P: Pathophysiology of bronchial smooth muscle remodelling in asthma. Eur Respir J 2010, 36:1174-1184

7. Orsini MJ, Krymskaya VP, Eszterhas AJ, Benovic JL, Panettieri RA Jr, Penn RB: MAPK superfamily activation in human airway smooth muscle: mitogenesis requires prolonged p42/p44 activation. Am J Physiol 1999, 277:L479-L488.

8. Simeone-Penney MC, Severgnini M, Rozo L, Takahashi S, Cochran BH, Simon AR: PDGF-induced human airway smooth muscle cell proliferation requires STAT3 and the small GTPase Rac1. Am J Physiol Lung Cell Mol Physiol 2008, 294:L698-L704.

9. Peat JK, Toelle BG, Dermand J, van den Berg R, Britton WJ, Woolcock AJ: Serum IgE levels, atopy, and asthma in young adults: results from a longitudinal cohort study. Allergy 1996, 51:804-810.

10. Souhrada M, Souhrada JF: Immunologically induced alterations of airway smooth muscle cell membrane. Science 1984, 225:723-725.

11. Gounni AS, Wellemans V, Yang J, Bellesort F, Kassiri K, Gangloff S, Guenounou M, Halayko AJ, Hamid Q, Lamkhioued B: Human airway smooth muscle cells express the high affinity receptor for IgE (Fc epsilon $\mathrm{RI})$ : a critical role of Fc epsilon RI in human airway smooth muscle cell function. J Immunol 2005, 175:2613-2621.

12. Roth M, Tamm M: The effects of omalizumab on IgE-induced cytokine synthesis by asthmatic airway smooth muscle cells. Ann Allergy Asthma Immunol 2010, 104:152-160.

13. Gounni AS: The high-affinity IgE receptor (FcepsilonRI): a critical regulator of airway smooth muscle cells? Am J Physiol Lung Cell Mol Physiol 2006, 291:L312-L321.

14. Redhu NS, Gounni AS: The high affinity IgE receptor (FcepsilonRI) expression and function in airway smooth muscle. Pulm Pharmacol Ther 2013, 26:86-94.

15. Redhu NS, Saleh A, Lee HC, Halayko AJ, Ziegler SF, Gounni AS: IgE induces transcriptional regulation of thymic stromal lymphopoietin in human airway smooth muscle cells. J Allergy Clin Immunol 2011, 128:892-896. e892.

16. Roth M, Zhong J, Zumkeller C, S'Ng CT, Goulet S, Tamm M: The role of IgEreceptors in IgE-dependent airway smooth muscle cell remodelling. PLoS One 2013, 8:e56015

17. Redhu NS, Saleh A, Shan L, Gerthoffer WT, Kung SK, Halayko AJ, Lamkhioued B, Gounni AS: Proinflammatory and Th2 cytokines regulate the high affinity lgE receptor (FcepsilonRI) and IgE-dependant activation of human airway smooth muscle cells. PLoS One 2009, 4:e6153.

18. Gosens R, Stelmack GL, Dueck G, McNeill KD, Yamasaki A, Gerthoffer WT, Unruh H, Gounni AS, Zaagsma J, Halayko AJ: Role of caveolin-1 in p42/p44
MAP kinase activation and proliferation of human airway smooth muscle. Am J Physiol Lung Cell Mol Physiol 2006, 291:L523-L534.

19. Goncharova EA, Lim P, Goncharov DA, Eszterhas A, Panettieri RA Jr, Krymskaya VP: Assays for in vitro monitoring of proliferation of human airway smooth muscle (ASM) and human pulmonary arterial vascular smooth muscle (VSM) cells. Nat Protoc 2006, 1:2905-2908.

20. Shan L, Redhu NS, Saleh A, Halayko AJ, Chakir J, Gounni AS: Thymic stromal lymphopoietin receptor-mediated IL- 6 and CC/CXC chemokines expression in human airway smooth muscle cells: role of MAPKs (ERK1/ 2, p38, and JNK) and STAT3 pathways. J Immunol 2010, 184:7134-7143.

21. Saleh A, Shan L, Halayko AJ, Kung S, Gounni AS: Critical role for STAT3 in IL-17A-mediated CCL11 expression in human airway smooth muscle cells. J Immunol 2009, 182:3357-3365.

22. Siraganian RP, De Castro RO, Barbu EA, Zhang J: Mast cell signaling: the role of protein tyrosine kinase Syk, its activation and screening methods for new pathway participants. FEBS Lett 2010, 584:4933-4940.

23. Kinet JP: The high-affinity IgE receptor (Fc epsilon $\mathrm{RI})$ : from physiology to pathology. Annu Rev Immunol 1999, 17:931-972.

24. Sonnenblick A, Levy C, Razin E: Immunological trigger of mast cells by monomeric IgE: effect on microphthalmia transcription factor, STAT3 network of interactions. J Immunol 2005, 175:1450-1455.

25. Xia YC, Schuliga M, Shepherd M, Powell M, Harris T, Langenbach SY, Tan PS, Gerthoffer WT, Hogarth PM, Stewart AG, Mackay GA: Functional expression of IgG-Fc receptors in human airway smooth muscle cells. Am J Respir Cell Mol Biol 2011, 44:665-672.

26. Redhu NS, Shan L, Gounni AS: Fcepsilon receptor expression in human airway smooth muscle cells. Am J Respir Cell Mol Biol 2012, 46:559-560. author reply 560-551.

27. Margulis A, Nocka KH, Brennan AM, Deng B, Fleming M, Goldman SJ, Kasaian MT: Mast cell-dependent contraction of human airway smooth muscle cell-containing collagen gels: influence of cytokines, matrix metalloproteases, and serine proteases. J Immuno/ 2009, 183:1739-1750.

28. Kang JY, Kim JW, Kim JS, Kim SJ, Lee SH, Kwon SS, Kim YK, Moon HS, Song JS, Park SH, Lee SY: Inhibitory effects of anti-immunoglobulin $E$ antibodies on airway remodeling in a murine model of chronic asthma. J Asthma 2010, 47:374-380.

29. Hakonarson H, Carter C, Kim C, Grunstein MM: Altered expression and action of the low-affinity lgE receptor FcepsilonRII (CD23) in asthmatic airway smooth muscle. J Allergy Clin Immunol 1999, 104:575-584.

30. Yanagi $\mathrm{S}$, Inatome R, Takano T, Yamamura H: Syk expression and novel function in a wide variety of tissues. Biochem Biophys Res Commun 2001, 288:495-498.

31. Abtahian F, Guerriero A, Sebzda E, Lu MM, Zhou R, Mocsai A, Myers EE, Huang B, Jackson DG, Ferrari VA, et al: Regulation of blood and lymphatic vascular separation by signaling proteins SLP-76 and Syk. Science 2003, 299:247-251.

32. Coopman PJ, Do MT, Barth M, Bowden ET, Hayes AJ, Basyuk E, Blancato JK, Vezza PR, McLeskey SW, Mangeat PH, Mueller SC: The Syk tyrosine kinase suppresses malignant growth of human breast cancer cells. Nature 2000, 406:742-747.

33. Moroni M, Soldatenkov V, Zhang L, Zhang Y, Stoica G, Gehan E, Rashidi B, Singh B, Ozdemirli M, Mueller SC: Progressive loss of Syk and abnormal proliferation in breast cancer cells. Cancer Res 2004, 64:7346-7354.

34. Simeone-Penney MC, Severgnini M, Tu P, Homer RJ, Mariani TJ, Cohn L, Simon AR: Airway epithelial STAT3 is required for allergic inflammation in a murine model of asthma. J Immunol 2007, 178:6191-6199.

35. Walker TR, Moore SM, Lawson MF, Panettieri RA Jr, Chilvers ER: Plateletderived growth factor- $\mathrm{BB}$ and thrombin activate phosphoinositide 3kinase and protein kinase $B$ : role in mediating airway smooth muscle proliferation. Mol Pharmacol 1998, 54:1007-1015.

36. Nath P, Leung SY, Williams A, Noble A, Chakravarty SD, Luedtke GR, Medicherla S, Higgins LS, Protter A, Chung KF: Importance of p38 mitogenactivated protein kinase pathway in allergic airway remodelling and bronchial hyperresponsiveness. Eur J Pharmacol 2006, 544:160-167.

37. McWhinnie R, Pechkovsky DV, Zhou D, Lane D, Halayko AJ, Knight DA, Bai TR: Endothelin-1 induces hypertrophy and inhibits apoptosis in human airway smooth muscle cells. Am J Physiol Lung Cell Mol Physiol 2007, 292:L278-L286.

38. Kawakami T, Kitaura J: Mast cell survival and activation by $\lg E$ in the absence of antigen: a consideration of the biologic mechanisms and relevance. J Immunol 2005, 175:4167-4173. 
39. Asai K, Kitaura J, Kawakami Y, Yamagata N, Tsai M, Carbone DP, Liu FT, Gall SJ, Kawakami T: Regulation of mast cell survival by lgE. Immunity 2001, 14:791-800

40. Kalesnikoff J, Huber M, Lam V, Damen JE, Zhang J, Siraganian RP, Krystal G: Monomeric IgE stimulates signaling pathways in mast cells that lead to cytokine production and cell survival. Immunity 2001, 14:801-811.

41. Kitaura J, Song J, Tsai M, Asai K, Maeda-Yamamoto M, Mocsai A, Kawakami Y, Liu FT, Lowell CA, Barisas BG, et al: Evidence that lgE molecules mediate a spectrum of effects on mast cell survival and activation via aggregation of the FcepsilonRI. Proc Natl Acad Sci USA 2003, 100:12911-12916.

42. Katoh N, Kraft S, Wessendorf JH, Bieber T: The high-affinity IgE receptor (FcepsilonRI) blocks apoptosis in normal human monocytes. J Clin Invest 2000, 105:183-190

43. Xiang Z, Ahmed AA, Moller C, Nakayama K, Hatakeyama S, Nilsson G: Essential role of the prosurvival bcl-2 homologue A1 in mast cell survival after allergic activation. J Exp Med 2001, 194:1561-1569.

44. Bryce PJ, Miller ML, Miyajima I, Tsai M, Galli SJ, Oettgen HC: Immune sensitization in the skin is enhanced by antigen-independent effects of IgE. Immunity 2004, 20:381-392.

45. Kashiwakura J, Kawakami Y, Yuki K, Zajonc DM, Hasegawa S, Tomimori Y, Caplan B, Saito H, Furue M, Oettgen HC, et al: Polyclonal lgE induces mast cell survival and cytokine production. Allergol Int 2009, 58:411-419.

46. Holgate S, Casale T, Wenzel S, Bousquet J, Deniz Y, Reisner C: The antiinflammatory effects of omalizumab confirm the central role of lgE in allergic inflammation. J Allergy Clin Immunol 2005, 115:459-465.

47. Bousquet J, Cabrera P, Berkman N, Buhl R, Holgate S, Wenzel S, Fox H, Hedgecock S, Blogg M, Cioppa GD: The effect of treatment with omalizumab, an anti-lgE antibody, on asthma exacerbations and emergency medical visits in patients with severe persistent asthma. Allergy 2005, 60:302-308.

48. Hoshino M, Ohtawa J: Effects of adding omalizumab, an antiimmunoglobulin $\mathrm{E}$ antibody, on airway wall thickening in asthma. Respiration 2012, 83:520-528.

49. Riccio AM, Dal Negro RW, Micheletto C, De Ferrari L, Folli C, Chiappori A Canonica GW: Omalizumab modulates bronchial reticular basement membrane thickness and eosinophil infiltration in severe persistent allergic asthma patients. Int I Immunopathol Pharmacol 2012, 25:475-484.

50. Zhou JS, Sandomenico A, Severino V, Burton OT, Darling A, Oettgen HC, Ruvo M: An IgE receptor mimetic peptide (PepE) protects mice from IgE mediated anaphylaxis. Mol Biosyst 2013, 9:2853-2859.

doi:10.1186/1710-1492-9-41

Cite this article as: Redhu et al: IgE induces proliferation in human airway smooth muscle cells: role of MAPK and STAT3 pathways. Allergy, Asthma \& Clinical Immunology 2013 9:41.

\section{Submit your next manuscript to BioMed Central and take full advantage of:}

- Convenient online submission

- Thorough peer review

- No space constraints or color figure charges

- Immediate publication on acceptance

- Inclusion in PubMed, CAS, Scopus and Google Scholar

- Research which is freely available for redistribution 